\title{
Want to be Entrepreneurial, you need to be APRIC: A Sand Cone Model of
}

\section{Entrepreneurial Orientation}

\begin{abstract}
Much of the literature on Entrepreneurial orientation (EO) is typified by the substantial benefits it brings, thus it is a characteristic that is highly desirable by businesses. However fundamentally, it is seen an in innate characteristic of a firm, either present or not, with little research questioning whether and how EO can be developed- this investigation challenges this preconception. Inspired by the famous Sand cone model of operational capability, we conceptualise that EO can be constructed in a sequential, cumulative fashion, starting with Autonomy, then Proactiveness, Risk Taking, Innovativeness, and finally Competitive Aggression (the APRIC framework). Using a two-stage testing methodology in SmartPLS and a sample of 200 respondents, we find partial support for our framework which inspires confidence in our assumption that EO can be developed. Two further research streams are therefore suggested- those that continue the work on investigating the sequences to developing EO, congruent with much of the extant work done on the original Sand cone model; and those that examine the contingency factors that many influence the sequence.
\end{abstract}

Keywords: Entrepreneurial Orientation, Sand cone model, developing 


\section{INTRODUCTION}

The link between Entrepreneurial Orientation and performance is widely acknowledged, whether it be firm performance (Lumpkin and Dess, 1996, Wang, 2008, Rauch et al., 2009, Li et al., 2010), start-up performance (Lee et al., 2001), flexibility and agility (Handfield et al., 2009) or the acquisition of knowledge (Li et al., 2011). It would be natural then for an organization to want to develop such entrepreneurial capabilities in order to reap these delectable rewards. However, such studies view Entrepreneurial Orientation as an inherent and innate characteristic of these firms, or as an extensions of their founder/owner (Lumpkin and Dess, 1996). This un-pragmatic, post-hoc view provides little direction for firms looking to develop such a characteristic. The on-going debate on Mode 2 research exemplifies this point, which insists that much greater attention be placed in linking academic research to the needs to practice. Burgoyne and James (2006) suggest that research should be concerned with "solving some 'live' problem for those for whom the research is produced" (p304); Starkey and Madan (2001) point out the need for "actionable advice rather than reflexive analysis" (p4); and MacLean et al (2002) calls for excellence in both academic rigor and managerial relevance. As a potential consequence of this, Bartunek (2011) questioned what progress has been made in addressing the "double hurdle" of relevance and rigour in the 10 years since the need was originally identified. Consequently, this inquiry attempts to address the question of how can a firm develop an Entrepreneurial Orientation?

\section{THEORY AND HYPOTHESIS}

Entrepreneurial Orientation (EO hereafter) is conceptualised in a manner consistent with Lumpkin and Dess' (1996) five-dimensioned view. In addition to the three original dimensions of the Covin-Slevin and Miller models (i.e. risk taking, innovation and 
proactiveness; Covin and Slevin, 1989, Miller, 1983), Lumpkin and Dess' introduces the notion of autonomy and competitive aggression. While entrepreneurial orientation is broadly defined as a firm level characteristic, existing research has explored the relative impact of each of the dimensions in isolation, if with some consideration of moderating factors (Covin and Slevin, 1988, Covin and Slevin, 1989). The following sectors initially justified all five dimensions of EO, before drawing from a multi factor model to develop a cumulative framework of EO (the APRIC framework in Figure 1). This model illustrates how the different dimensions of EO are related and our proposed cumulative and sequential nature of EO development.

\section{INSERT FIG 1 HERE}

To advance the development of EO as "actionable advice" and begin the literary conversation on developing EO, we call upon the practical oriented domain of Operations Management. Operations management is explicit focused upon understanding organizations as processes, that can be deliberately changed to ensure organizational objectives are achieved (Slack et al. 2013). Specifically, we draw from the highly influential 'Sand Cone' model of operations capability by Ferdows and De Meyer's (1990) who argue that superior competitive capabilities can be developed in a specific, cumulative sequence. The model argues against the traditional trade-off view of operational capabilities (Skinner, 1974), instead suggesting different operational capabilities are complimentary. Ferdows and DeMeyer (1990) state that excellence in quality provides the foundation from with to build the subsequent capabilities of dependability, speed and cost. Noble (1995) later extended it with the addition of flexibility 
and innovation, so making an explicit link with the innovation within the EO model. The resulting 'Sand cone' model is illustrated in Figure 2 below.

\section{INSERT FIG 2 HERE}

The key insight we draw from this framework in relation to entrepreneurship is three-fold. Firstly, due to the context of the study being entrepreneurship rather than operations management, we will be substituting operational capabilities with entrepreneurial capabilities. This means that within Figure 2, the separate capabilities of quality, dependability, speed, cost, flexibility and innovation, will be substitutes with autonomy, proactiveness, risk-taking, innovation and competitive aggression. By separating the different elements of entrepreneurial orientation and presenting them within a sequence, the framework will support the focusing of managerial attention towards specific actions, which in turn provide more achievable aims. Secondly, that these individual competencies are cumulative in nature, which is key to increasing the practical utility of the concept of EO. This challenges the view by the EO-Performance studies listed earlier which effectively view EO as binary- either being present or absent, present in its entirety or not at all. Instead, by viewing EO as a journey of competence building, a more grey-scale, richer interpretation can be envisaged, a view congruent with our intension to aid the business and management community. Third and finally, by building from the previous point, competencies can be developed in a specific sequence with one competence being an extension of the previous. In doing so, taking a 'Sand cone' view to developing EO provides significant guidance on the 
strategies and prioritising of action, essential with limited managerial attention and resources to allocate to improvement.

Following this initial broad justification for the structure of the cumulative model of EO, the following section presents each of the elements of EO in turn, to illustrate its position within our "Sand cone" model of entrepreneurial orientation, the APRIC framework.

\section{Stage 1: Autonomy}

Just as the foundation of operational capability is said to be quality (Ferdows and De Meyer, 1990), we view autonomy as being this key-stone to entrepreneurial orientation. Burgelman (1983) argues that the bottom-up process of "autonomous strategic initiatives" is the driving force behind corporate entrepreneurship, and more recent work by Lumpkin et al. (2009; p48) suggest that that "autonomy is an antecedent of entrepreneurial behaviour". Furthermore, on the interface of operations management and entrepreneurship, Goodale et al. (2011) suggest that "entrepreneurial opportunities are often best recognized by those with discretion over how to perform their work" (p119). In this way, autonomy is the extent to which decisionmaking latitude and freedom from oversight is provided.

The manifestation of this is that without the autonomy and freedom to identify opportunities, making decisions or initiate change, it would not be possible to take initiatives (i.e. Proactiveness), there would no opportunities to engage in experimentation (i.e. Risk taking) and the cultural ethos of control would stifle creativity (i.e. Innovativeness), and sufficing would be the norm with little desire to succeed (i.e. Competitive aggression). Critically, while EO is often associated with the founder/owner of the company (Lumpkin and Dess, 1996), who by definition has autonomy of their actions, to be entrepreneurial, it would still be 
necessary for them to act in an autonomous way to exhibit entrepreneurial behaviour. Therefore, without autonomous behaviour within the individual, there would be little or no entrepreneurial activities, suggesting that:

Hypothesis 1: Autonomy provides the basis to entrepreneurial orientation.

\section{Stage 2: Proactiveness}

Lumpkin and Dess (1996) describe proactiveness as "forward looking" and is consistent with the notion of entrepreneurship as new entry (Li et al., 2011, Lumpkin and Dess, 1996) and the focus on seeking opportunities (Miller, 1983, Lumpkin and Dess, 2001, Rauch et al., 2009). In combination with autonomy, proactiveness implies the luxury of choice, discretion in the allocation of resource and to a degree self-determination, albeit for opportunity seeking. While autonomy in isolation may be a prerequisite for EO, proactiveness represents a central element (Burgelman, 1983), allowing individuals and organizational to pursued and capitalise on identified opportunities. Such proactive behaviour also provides benefits from autonomy, helping build appreciation of the need for greater levels of autonomy when increasing the level of proactiveness. Thus once equipped with the right of self-management (i.e. autonomy), taking initiative to identify opportunities is a logical extension, whether in the form of correcting problems or pursuing new market opportunities. Consistent with Lumpkin and Dess (1996), the addition of proactiveness then provides greater strategic direction, while also leading to improved performance (Lumpkin and Dess, 2001).

Hypothesis 2: Autonomy is a prerequisite for proactiveness. 


\section{Stage 3: Risk taking}

Having the freedom to pursue opportunities and the proactive drive to take the initiative may result in short term gains through the seizure of "low hanging fruit". However, where higher levels of change or large opportunities want to be realised, it may necessitate the allocation of resources to activities that have a degree of uncertainty in their results and so the introduction of risk. For example, if there is not uncertainty in development opportunities, there are not opportunities to pursue ventures different to competitors and create a competitive advantage. Risk taking is thus the willingness of management to support the opportunities identified via the proactive phase, and commit organizational resources in the pursuit of these opportunities with uncertain return (Raunch, 2009). In doing so, risk taking instils the confidence to move into new directions, helping prevent the development of counter-productive organizational routines (Leonard-Barton, 1992), that may limit further entrepreneurial behaviour. An important factor within risk taking is thus the acceptance of failure, which is often omitted from the outcomes of firm-level entrepreneurial activity (Guth and Ginsberg, 1990, Antoncic and Hisrich, 2001). In summary, the ability to identify opportunities (i.e. pro-activeness) provides the reason for risk taking; which itself is determined by having being able to do what you want (i.e. autonomy).

\section{Hypothesis 3: Autonomy and Proactiveness are prerequisite for Risk-taking}

\section{Stage 4: Innovation}

Amongst other definitions, which this paper does not attempt to concern itself with, innovation is seen as the "the implementation of the results of creativity" (McAdam and McClelland, 2002; p87). The previous three phases provide the scope within individuals to foster an inquisitive entrepreneurial mindset (McGrath and MacMillan, 2000) and the 
confidence to employ resources to examine opportunities, even without certainty about the organisational outcomes. However what is missing is a direct focus on commercialising, implementing or realising value through the creation of novel and unique solutions. Thus, the innovation stage is focused on realising outcomes from risk taking behaviours that are new, novel and unique, and are aligned with the firm's organizational strategy. Further, Covin and Miles' (1999) adds that "without innovation there is no corporate entrepreneurship regardless of the presence of these other dimensions [in particular reference to risk taking and proactiveness]" (p. 49). The authors go on to suggest that while innovation is a necessary; it is not a sufficient condition of being truly entrepreneurial, advocating the indispensability of the aforementioned stages. In addition, due to innovation being consistently being related to firm performance (Levinthal and March, 1993, Cho and Pucik, 2005, Newbert, 2008, Terziovski, 2010) efforts directed towards performance improvement should focus on innovative outcomes. Critically drawing from such discussions, it is necessary to appreciate that for the development of something new, novel and innovative, there is inherent risks involved in doing something that has not been done before (March, 1991, Levinthal and March, 1993). Consequently, if risk taking behaviours are to result in a positive contribution to firm performance, they need to result in innovative outcomes, and without risk taking behaviours, there is a limited chance of there being innovative outcomes. Consequently, an innovation could be viewed as a strategically aligned deliverable of a risk-taking activity, and thus more strongly related to performance then risk taking alone.

Hypothesis 4: Innovation requires a prerequisite of autonomy, proactiveness, and risk-taking 


\section{Stage 5: Competitive Aggression}

Competitive aggression is defined as a "firm's propensity to directly and intensely challenge its competitors" (Lumpkin and Dess, 1996; p148). To realise benefits from competitive aggression, it is proposed that firms need to provide the freedom (i.e. autonomy) to pursue opportunities (i.e. proactiveness) that stretches the firm (i.e. risk taking) resulting in materialised, strategically aligned, value (i.e. innovation). Competitive aggressions also focused on the effective use of resources to achieve a competitive advantage, through more aggressive marketing for example, resulting in increased performance of given innovations. From an alternate perspective, Covin and Miles (1999) suggest that strategic renewal is dependent on a innovation. Firms with intense levels of competitive aggression may engage in risk taking and innovation to such an extent as to fundamentally change business process and reposition themselves to market sectors in which they are able to perform better. Thus, Covin and Miles (1999) reinforces the notion that that competitive aggression must follow on from innovation, that itself builds on risk taking.

We also note a caveat to the role of competitive aggression due to a situation we choose to call "the growth paradox". Firms may consciously choose to not to act in an aggressive manner as they may be satisfied with their current level of exposure and firm size. If firms are innovative and pursue aggressive behaviour, it is likely that there will be a greater increase in turn over, sales volumes and market share, and to account for this, growth in the firm. This, however, may have two adverse effects on entrepreneurial behaviour. Firstly, greater mechanistic structures and procedures may be implemented in order to exercise control on operational processes. Covin and Slevin (1988) showed that such structures stifled entrepreneurial behaviour and reduced firm performance. Secondly, firm growth may also result in an increases in the employee numbers (Lockett et al., 2011), which may dilute the 
original entrepreneurial spirit of the firm and hence its overall entrepreneurial tendencies. For example, the rapid recruitment of staff may inhibit socialisation processes necessary to maintain the firm level attributes that originally promoted their success. Notwithstanding this paradox, we suggest the fifth hypothesis, while accepting that firms may not necessarily pursue competitive aggression, but when build on a foundation of innovation are likely to perform better.

Hypothesis 5: Competitive aggression requires a prerequisite of autonomy, proactiveness, risk-taking and innovation

\section{METHODS}

\section{Data Collection and Sample}

The survey was developed via the web-based survey platform, surveymonkey. Respondents were sourced via LinkedIn, a professional social network, as it provides a means of viewing "virtual CVs" which enabled individuals with specific expertise and experience to be targeted. This level of detail is not possible through traditional administration modes such as professional associations or Institutes. The survey was administered to candidates in a twostep process. Firstly, as part of a broader research project on process improvement/ innovation, a total of six special interest boards were identified which had specific interest in the area of process improvement/ innovation. Following this, 2056 customised cover letters detailing the motivations for and benefits of the research were distributed with a web-link to the survey. 
Following a four stage data purification methodology as guided by Hair et al. (2006) and as summarised in Table 1 below, a total of 200 useable responses were received, giving a response rate of $9.7 \%$. This response rate is comparable to other web-based studies (Cousins et al., 2006- 14.8\%). Noting, a key assumption for structural equation modelling (SEM) is multivariate normality, however the vast majority of studies do not report or formally test this assumption. As per to Hair et al. (2006) methodology, and guided by DeCarlo's (1997) Looney's (1995) work, we used an omnibus test based on Small's (1980) Q3 statistic to test for multivariate normality- results were not significant suggesting the violation of MVN assumptions and the conclusion of non-multivariate data (Looney, 1995).

\section{INSERT TABLE 1 HERE}

\section{Analytical Procedures}

SmartPLS (Ringle et al., 2005) was used to analyse the data as it is not constrained by distributional assumptions; hence the violation of the multivariate normality assumption in the table above, which would nullify the use of LISREL, is fully acceptable in PLS.

To test our hypothesised sequence, we again draw from the operations management literature for guidance. Of the various studies that have tested the original Sand cone model of operational capability by Ferdows and De Meyer's (1990), Schroeder et al's (2011) approach was identified as the most rigorous and what we adopt here. The greater level of rigour is attributed to the use of two discrete tests; first to demonstrate association amongst the dimensions and their cumulative indirect effects, a mediation test is first suggested. Using structural equation modelling (SEM), a path analysis can be conducted with the goal being 
that "the direct effect between non-adjacent performance dimensions should be smaller than its indirect effect" (Schroeder et al., 2011; p4885). The original approach used $\chi^{2}$ difference test to determine the significance of mediation effect, however as previously stated, covariance-based SEM could not be used due to the violation of the multivariate normality assumption. Instead, we examine the mediation effect in two parts- the significance of the indirect effect using the Sobel test and bootstrapping (Baron and Kenny, 1986, Zhao et al., 2010, Esposito Vinzi et al., 2010), then the effect size of the mediation using the Variance Accounted For (VAF) and a PLS-based goodness of fit measure Gof $=\sqrt{\text { Ave.Communality } \times \text { Ave. } R^{2}}$ (Camisón and Villar-López, 2012, Tenenhaus et al., 2005, Esposito Vinzi et al., 2010) ${ }^{1}$.

According to Schroeder et al (2011), while the before mentioned test demonstrates association, it does not test the sequence itself. Based on the assumption that operational capabilities can be developed, Schroeder et al (2011) suggest that different firms should have varying levels of competence across each of the dimensions. Using this, they divided each of the performance dimensions (quality $\mathrm{Q}>$ dependability $\mathrm{D}>$ flexibility $\mathrm{F}>\operatorname{cost} \mathrm{C}$ ) into high (H) and low (L) levels using the median and categorise the cases into one of the 16 possible sequences $^{2}$. The test is then to examine whether the majority of the cases $(>50 \%)$ conform to the hypothesised sequence, for example QH-DH-FH-CL is possible but QH-DH-FL-CH is not as the cost dimension should evolve before the flexibility dimension. Within the current research, this resulted in the data being categorised into 25 possible sequences, due to each of the 5 attributed having 2 choices.

\footnotetext{
${ }^{1}$ The referenced authors recommended minimum of 0.31

24 dimensions by 2 choices
} 


\section{Measures}

Entrepreneurial Orientation. There is considerable literature on the measures for entrepreneurial orientation, ranging from the original nine-item scale by Miller (1983) to Lumpkin et al.'s (2009) more recent works. Upon extensive review of the key literature on entrepreneurial orientation (c.f. Brown et al., 2001, Covin et al., 2006, Covin and Slevin, 1988, Kreiser et al., 2002, Kropp et al., 2008, Lumpkin et al., 2009, Lumpkin and Dess, 1996, Lumpkin and Dess, 2001, Rauch et al., 2009, Wang, 2008), a nine-item measure of risktaking (e.g. taking calculated risks, experimentation), proactiveness (e.g.. identifying opportunities, initiate actions) and innovativeness (e.g. creative, actively introduce innovations) developed and employed by Hughes et al. (2007) was used as the contextual wording of this construct was more closely aligned with this study. Additionally, autonomy was measured using the 4-item scale by Lumpkin et al (2009); and competitive aggression was measured on the 2-items scale by Lumpkin and Dess (2001)- the Appendix details the survey items.

Radicalness. Building upon the relationship between innovativeness and firm performance, the radicalness of innovation is measured, to provide a means of represent the extent of positive outcomes of the Sand cone model. This measure of innovation radicalness provides a means of relating the proposed model and sequence to an outcome of the model for completeness. Consequently, the five-item scale developed by Gatignon et al. (2002; alpha $=0.78)$ and later confirmed by Pérez-Luño et al. $(2011$; alpha $=0.90)$ was included. 


\section{ANALYSIS AND RESULTS}

\section{Mediation Test}

SmartPLS (Ringle et al., 2005) using the default settings of case-wise replacement of missing information, path weighting scheme, and 500 bootstrap resamples for path significance was used (Henseler et al., 2009, Ringle and Henseler, 2011, Peng and Lai, 2012, Camisón and Villar-López, 2012). The measurement model was tested using Cronbach alpha, composite reliability and average variance extracted in accordance with Henseler et al.(2009). Initial analysis showed poor loadings of RAD1 in the radicalness construct, A4 in the autonomy construct, and $\mathrm{C} 2$ in the competitive aggression construct and so were removed (see appendix for details on the items). The resulting measurement model performance are summarised below and meet all standard criteria.

\section{INSERT TABLE 2 HERE}

To assess the hypothesis and the structural model, an iterative approach was taken as per Schroeder et al (2011), with the significance and effect of the indirect effect measured at each iteration (c.f. Esposito Vinzi et al., 2010). As Table 3 below shows, the conceptual model (Model 1) demonstrates strong path loadings across the APRIC framework, and that all paths are strongly significant $(t>1.96)$. The goodness of fit measure is also adequate as it is above the recommended 0.31 level (c.f. Camisón and Villar-López, 2012). In the first two iterations of the conceptual model, the direct effect of autonomy on risk taking (Model 2) and proactiveness on innovation (Model 3) is examined in order to test eh indirect/mediating 
effect of proactiveness and risk taking respectively. Similar to Model 1, all APRIC paths are significant, with the indirect effects also significant $(t>1.96)$ and of sufficient effect size (>50\%) (Esposito Vinzi et al., 2010). However, the direct effects (A -> R and P -> I) are also both significant, suggesting only a partial mediation effect. The final model examines the direct effect of risk taking on competitive aggression and similar to the previous iterations, the indirect effect is both significant and of good effect size. The exception here is that the direct effect is not significant $(t<1.96)$, suggesting a full mediating effect, which may also account for the higher VAF value.

INSERT TABLE 3 HERE

\section{Sequence Test}

As outlined above and by Schroeder et al's (2011), while the previously mentioned test demonstrates association, it does not test the sequence itself and so is not fully sufficient to conclude the sequential nature of our APRIC conceptual framework. Table 4 below constructs all possible sequences that can be exhibited by sorting the cases into high and low groups based on the median. We then list all the percentage of cases that can be attributed to each combination, and whether the sequence is in accord with the APRIC framework, noting that there are only 6 possible combinations that are in accordance with this.

Using a similar illustration to Schroeder et al (2011), the results show that 42 cases $(21 \%)$ have a AL-PL-RL-IL-CL sequence, in other works they are yet to start on the entrepreneurial journey since all five lows are low. Conversely, $5 \%$ of cases are well underway in developing 
full entrepreneurial orientation (AH-PH-RH-IH-CL). However, the cumulative nature of our hypothesised development of EO suggests that low levels eventually become high levels; and the sequential nature of nature of our hypothesised development of EO suggests that low levels should only occur at certain stages of development. Subsequently, sequences that exhibit a low (L) status to the left-hand side of any high $(\mathrm{H})$ is not congruent with this cumulative nature and is therefore not possible, for example a AH-PH-RL-IH-CL sequence is not possible as it violates Hypothesis 4 that Innovation requires a prerequisite of autonomy, proactiveness, AND risk-taking.

INSERT TABLE 4 HERE

Finally, as Table 4 highlights, $47 \%$ of cases follow the APRIC sequence. Although a sizeable portion of the data, it does highlight that the sequence is followed by some, but not all, suggestive that contingencies factors are also at play. Given this, it leads us to conclude that our five hypotheses and the APRIC framework is partially supported.

\section{DISCUSSION}

\section{Theoretical Implications}

This study set out to challenge existing preconceptions that Entrepreneurial Orientation is an inherent and binary organizational characteristic. Instead, we introduce the notion that EO can be developed in a sequential and cumulative fashion by drawing from the well established Sand cone model of operational capability development (Ferdows and De Meyer, 
1990, Schroeder et al., 2011). Our series of mediation tests demonstrate that the underlying structure of our APRIC framework is congruent, yet the sequential test demonstrated that other contingency factors also need to be accounted for. This has two key implications. Firstly, it is in agreement to our initial assumption that EO can be developed and joins some emerging literature that suggests a more greyscale interpretation of EO. For example, Wales et al. (2011) challenge the assumption that EO is vertically (hierarchically), horizontally (across business units) and temporally (time-wise) homogenous throughout the organization. Secondly, by reporting a cumulative sequence to developing EO, it provides insight that addresses Lumpkin and Dess' (1996) concerns that "the extent to which each of these dimensions is useful for predicting the nature and success of a new undertaking may be contingent on external factors, such as the industry or business environment, or internal factors, such as the organization structure.” (p175).

\section{Managerial Implications and Further Research}

This research sheds light on the strategies and assessments necessary for developing EO. While the finding are of profound interest to managers looking to elevate their organization's level of entrepreneurship and achieve the many performance gains purported by EO, the discourse on how to develop EO is still in its infancy. Therefore we see two key streams of research to further this; first are those to replicate, challenge or extend our initial APRIC sequence. This stream would replicates much of the thinking and progression done in the initial Sand cone model of operational capabilities (c.f. Noble, 1995). Secondly, are those studies that would further the contingency perspective and Lumpkin and Dess' (1996) concerns by exploring those traits that may account for the variation on the way organizations have evolved, or may well evolve. 


\section{REFERENCES}

ANTONCIC, B. \& HISRICH, R. D. 2001. Intrapreneurship: Construct refinement and crosscultural validation. Journal of Business Venturing, 16, 495-527.

BARON, R. M. \& KENNY, D. A. 1986. The moderator-mediator variable distinction in social psychological research: Conceptual, strategic, and statistical considerations. Journal of Personality and Social Psychology, 51, 1173-1182.

BARTUNEK, J. M. 2011. What Has Happened to Mode 2? British Journal of Management, 22, 555-558.

BROWN, T. E., DAVIDSSON, P. \& WIKLUND, J. 2001. An operationalization of Stevenson's conceptualization of entrepreneurship as opportunity-based firm behavior. Strategic Management Journal, 22, 953-968.

BURGELMAN, R. A. 1983. A Model of the Interaction of Strategic Behavior, Corporate Context, and the Concept of Strategy. Academy of Management Review, 8, 61-70.

BURGOYNE, J. \& JAMES, K. T. 2006. Towards Best or Better Practice in Corporate Leadership Development: Operational Issues in Mode 2 and Design Science research. British Journal of Management, 17, 303-316.

CAMISÓN, C. \& VILLAR-LÓPEZ, A. 2012. On How Firms Located in an Industrial District Profit from Knowledge Spillovers: Adoption of an Organic Structure and Innovation Capabilities. British Journal of Management, 23, 361-382.

CHO, H. J. \& PUCIK, V. 2005. Relationship between innovativeness, quality, growth, profitability, and market value. Strategic Management Journal, 26, 555-575.

COUSINS, P. D., HANDFIELD, R. B., LAWSON, B. \& PETERSEN, K. J. 2006. Creating supply chain relational capital: The impact of formal and informal socialization processes. Journal of Operations Management, 24, 851-863.

COVIN, J. G., GREEN, K. M. \& SLEVIN, D. P. 2006. Strategic Process Effects on the Entrepreneurial Orientation-Sales Growth Rate Relationship. Entrepreneurship Theory and Practice, 30, 57-81.

COVIN, J. G. \& MILES, M. 1999. The Pursuit of Competitive Advantage. Entrepreneurship Theory and Practice, 23, 47-63.

COVIN, J. G. \& SLEVIN, D. P. 1988. THE INFLUENCE OF ORGANIZATION STRUCTURE ON THE UTILITY OF AN ENTREPRENEURIAL TOP MANAGEMENT STYLE. Journal of Management Studies, 25, 217-234.

COVIN, J. G. \& SLEVIN, D. P. 1989. Strategic management of small firms in hostile and benign environments. Strategic Management Journal, 10, 75-87.

DECARLO, L. T. 1997. On the meaning and use of kurtosis. Psychological Methods, 2, 292307.

ESPOSITO VINZI, V., CHIN, W. W., HENSELER, J. \& WANG, H. 2010. Handbook of Partial Least Squares: Concepts, Methods and Applications, Berlin, Heidelberg, Springer

FERDOWS, K. \& DE MEYER, A. 1990. Lasting Improvements in Manufacturing Performance: In Search of a New Theory. Journal of Operations Management, 9, 168-184.

GATIGNON, H., TUSHMAN, M. L., SMITH, W. \& ANDERSON, P. 2002. A Structural Approach to Assessing Innovation: Construct Development of Innovation Locus, Type, and Characteristics. Management Science, 48, 1103-1122.

GOODALE, J. C., KURATKO, D. F., HORNSBY, J. S. \& COVIN, J. G. 2011. Operations management and corporate entrepreneurship: The moderating effect of operations control on the antecedents of corporate entrepreneurial activity in relation to innovation performance. Journal of Operations Management, 29, 116-127. 
GUTH, W. \& GINSBERG, A. 1990. Guest Editors' Introduction: Corporate Entrepreneurship. Strategic Management Journal, 2, 5-15.

HAIR, J. F., BLACK, W. C., BLACK, B. J. \& ANDERSON, R. E. 2006. Multivariate data analysis, Upper Saddle River, N.J, Pearson/Prentice Hall.

HANDFIELD, R., PETERSEN, K., COUSINS, P. \& LAWSON, B. 2009. An organizational entrepreneurship model of supply management integration and performance outcomes. international Journal of Operations \& Production Management, 29, 100126.

HENSELER, J., RINGLE, C. M. \& SINKOVICS, R. R. 2009. The use of partial least squares path modeling in international marketing. Advances in international marketing, 20, 277-319.

HUGHES, M., HUGHES, P. \& MORGAN, R. E. 2007. Exploitative Learning and Entrepreneurial Orientation Alignment in Emerging Young Firms: Implications for Market and Response Performance. British Journal of Management, 18, 359-375.

KREISER, P. M., MARINO, L. D. \& WEAVER, K. M. 2002. Assessing the Psychometric Properties of the Entrepreneurial Orientation Scale: A Multi-Country Analysis. Entrepreneurship: Theory \& Practice, 26.

KROPP, F., LINDSAY, N. J. \& SHOHAM, A. 2008. Entrepreneurial orientation and international entrepreneurial business venture startup. International Journal of Entrepreneurial Behaviour \& Research, 14, 102-117.

LEE, C., LEE, K. \& PENNINGS, J. M. 2001. Internal capabilities, external networks, and performance: a study on technology-based ventures. Strategic Management Journal, 22, 615-640.

LEONARD-BARTON, D. 1992. Core Capabilities and Core Rigidities: A Paradox in Managing New Product Development. Strategic Management Journal, 13, 111-125.

LEVINTHAL, D. A. \& MARCH, J. G. 1993. The myopia of learning. Strategic Management Journal, 14, 95-112.

LI, Y., LIU, Y. \& LIU, H. 2011. Co-opetition, distributor's entrepreneurial orientation and manufacturer's knowledge acquisition: Evidence from China. Journal of Operations Management, 29, 128-142.

LI, Y., WEI, Z. \& LIU, Y. 2010. Strategic Orientations, Knowledge Acquisition, and Firm Performance: The Perspective of the Vendor in Cross-Border Outsourcing. Journal of Management Studies, 47, 1457-1482.

LOCKETT, A., WIKLUND, J., DAVIDSSON, P. \& GIRMA, S. 2011. Organic and Acquisitive Growth: Re-examining, Testing and Extending Penrose's Growth Theory. Journal of Management Studies, 48, 48-74.

LOONEY, S. W. 1995. How to Use Tests for Univariate Normality to Assess Multivariate Normality. The American Statistician, 49, 64-70.

LUMPKIN, G. T., COGLISER, C. C. \& SCHNEIDER, D. R. 2009. Understanding and Measuring Autonomy: An Entrepreneurial Orientation Perspective. Entrepreneurship Theory and Practice, 33, 47-69.

LUMPKIN, G. T. \& DESS, G. G. 1996. Clarifying the Entrepreneurial Orientation Construct and Linking It to Performance. Academy of Management Review, 21, 135-172.

LUMPKIN, G. T. \& DESS, G. G. 2001. Linking two dimensions of entrepreneurial orientation to firm performance: The moderating role of environment and industry life cycle. Journal of Business Venturing, 16, 429-451.

MACLEAN, D., MACINTOSH, R. \& GRANT, S. 2002. Mode 2 Management Research. British Journal of Management, 13, 189-207.

MARCH, J. G. 1991. Exploration and exploitation in organizational learning. Organization Science, 2, 71-87. 
MCADAM, R. \& MCCLELLAND, J. 2002. Individual and team-based idea generation within innovation management- Organisational and research agendas. European Journal of Innovation Management, 5, 86-97.

MCGRATH, R. M. \& MACMILLAN, I. C. 2000. The Entrepreneurial Mindset, Boston, Harvard Business School Press.

MILLER, D. 1983. The correlates of entrepreneurship in three types of firms. Management Science, 29, 770-791.

NEWBERT, S. L. 2008. Value, rareness, competitive advantage, and performance: A conceptual level empirical investigation of the resource based view of the firm. Strategic Management Journal, 29, 745-768.

NOBLE, M. A. 1995. Manufacturing Strategy: Testing the Cumulative Model in a Multiple Country Context. Decision Science, 26, 693-721.

PENG, D. X. \& LAI, F. 2012. Using partial least squares in operations management research: A practical guideline and summary of past research. Journal of Operations Management, 30, 467-480.

PÉREZ-LUÑO, A., CABELLO MEDINA, C., CARMONA LAVADO, A. \& CUEVAS RODRÍGUEZ, G. 2011. How social capital and knowledge affect innovation. Journal of Business Research, 64, 1369-1376.

RAUCH, A., WIKLUND, J., LUMPKIN, G. T. \& FRESE, M. 2009. Entrepreneurial Orientation and Business Performance: An Assessment of Past Research and Suggestions for the Future. Entrepreneurship Theory and Practice, 33, 761-787.

RINGLE, C. M. \& HENSELER, J. 2011. PLS Path Modelling: Introduction and Application. In: WWW.PLS-SCHOOL.COM (ed.). Nottingham, UK.

RINGLE, C. M., WENDE, S. \& WILL, A. 2005. SmartPLS 2.0 (M3), Hamburg: http://www.smartpls.de.

SCHROEDER, R., SHAH, R. \& PENG, D. X. 2011. The cumulative capability 'sand cone' model revisited: a new perspective for manufacturing strategy. International Journal of Production Research, 49, 4879-4901.

SKINNER, W. 1974. The focused factory. Harvard Business Review, 113-121.

SMALL, N. J. H. 1980. Marginal Skewness and Kurtosis in Testing Multivariate Normality. Journal of the Royal Statistical Society. Series C (Applied Statistics), 29, 85-87.

STARKEY, K. \& MADAN, P. 2001. Bridging the relevance gap: aligning stakeholders in the future of management research. British Journal of Management, 12, Special Issue, S3-S26.

TENENHAUS, M., VINZI, V. E., CHATELIN, Y.-M. \& LAURO, C. 2005. PLS path modeling. Computational Statistics \& Data Analysis, 48, 159-205.

TERZIOVSKI, M. 2010. Innovation practice and its performance implications in small and medium enterprises (SMEs) in the manufacturing sector: a resource-based view. Strategic Management Journal, 31, 892-902.

WALES, W., MONSEN, E. \& MCKELVIE, A. 2011. The Organizational Pervasiveness of Entrepreneurial Orientation. Entrepreneurship Theory and Practice, 35, 895-923.

WANG, C. L. 2008. Entrepreneurial Orientation, Learning Orientation, and Firm Performance. Entrepreneurship Theory and Practice, 32, 635-657.

ZHAO, X., LYNCH JR., J. G. \& CHEN, Q. 2010. Reconsidering Baron and Kenny: Myths and Truths about Mediation Analysis. The Journal of Consumer Research, 37, 197206. 


\section{APPENDIX: SURVEY INSTRUMENT}

Firm-level Entrepreneurial Orientation: Regarding your firm, to what extent would you agree with the following?

7-point scale from "'strongly disagree" to "strongly agree",

(Autonomy)

A1.My firm supports the efforts of individuals and/or teams that work autonomously as compared with requiring individuals and/or teams to rely on senior managers to guide their work.

A2. The managers of my firm believe that the best results occur when individuals and/or teams (rather than the CEO and top managers) decide for themselves what improvement opportunities to pursue

A3.In my firm, the CEO and top management team (rather than employee initiatives and input) play a major role in identifying and selecting the improvement opportunities my firm pursues

A4.In my firm, individuals and/or teams pursuing improvement opportunities make decisions on their own without constantly referring to their supervisors (instead of having to obtain approval from supervisors)

(Proactiveness)

P1. We excel at identifying opportunities

P2. We always try to take the initiative in every situation (e.g. against competitors, in projects and when working with others)

P3. We initiate actions to which other organizations respond

(Risk Taking)

R1.Our business emphasizes both exploration and experimentation for opportunities

$\mathrm{R} 2$. People in our business are encouraged to take calculated risks with new ideas

R3. Our business frequently tries out new ideas (Innovativeness)

I1. Our business is creative in its methods of operation

I2. Our business is often the first to market with new products and services

I3. We actively introduce improvements and innovations in our business

(Competitive Aggressiveness)

$\mathrm{C} 1$. My firm is very aggressive and intensely competitive rather than making no special effort to take business from the competition

C2.In dealing with competitors, my firm typically seeks to avoid competitive clashes, preferring a "live-and-let-live" posture (rather than a competitive "undo-thecompetitors" posture)

Radicalness: In the previous 2-3 years, the new or improved products/services/processes introduced by your company as a result of improvement initiatives:

7-point scale from "strongly disagree" to "strongly agree",

RAD1. Represented a minor improvement over the previous technology

RAD2. Were based on a revolutionary change in technology

RAD3. Were a breakthrough innovation

RAD4. Led to products/processes that were difficult to replace with substitutes using older technology

RAD5. Represented a major technological advance in the subsystems. 
Figure 1: Conceptual Framework

\begin{tabular}{|c|c|c|c|c|}
\hline $\begin{array}{l}\text { Autonomy } \\
\text { (A) }\end{array}$ & $\begin{array}{l}\text { Proactiveness } \\
\text { (P) }\end{array}$ & $\begin{array}{c}\text { Risk taking } \\
\text { (R) }\end{array}$ & $\begin{array}{l}\text { Innovation } \\
\text { (I) }\end{array}$ & $\begin{array}{c}\text { Competitive } \\
\text { Aggression (C) }\end{array}$ \\
\hline
\end{tabular}

Figure 2: the Sand cone model of cumulative operational capabilities

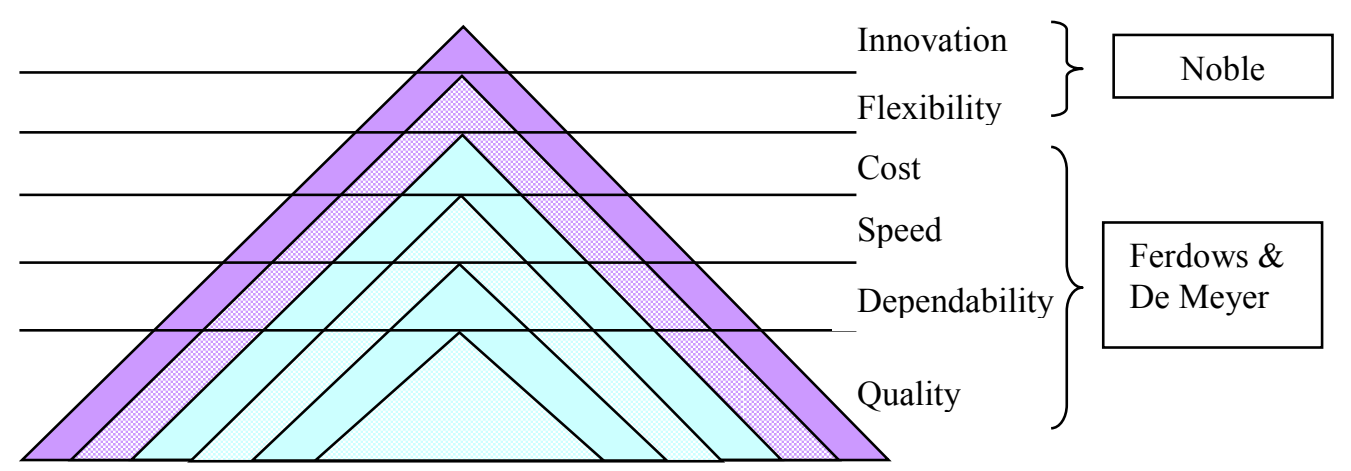

Table 1: Summary of Data Purification

\begin{tabular}{ccccc}
\hline $\begin{array}{c}\text { Total } \\
\text { Responses }\end{array}$ & $\begin{array}{c}\text { Stage 1: Case-wise } \\
\text { missing data }\end{array}$ & $\begin{array}{c}\text { Step 2: Variable- } \\
\text { wise missing data }\end{array}$ & $\begin{array}{c}\text { Step 3: Outlier } \\
\text { Analysis }\end{array}$ & $\begin{array}{c}\text { Step 4: } \\
\text { Normality }\end{array}$ \\
\hline & & & & $\begin{array}{l}\text { Multivariate } \\
\text { normality not met } \\
\text { but no cases removed }\end{array}$ \\
291 & 200 & 200 & 200 & $\begin{array}{l}\text { Total sample size: } \\
200\end{array}$ \\
\end{tabular}


Table 2: Measurement Model Results

\begin{tabular}{lccc}
\hline & $\begin{array}{c}\text { Composite Reliability } \\
(>\mathbf{0 . 6})\end{array}$ & $\begin{array}{c}\text { Cronbachs Alpha } \\
(>\mathbf{0 . 7})\end{array}$ & $\begin{array}{c}\text { AVE } \\
(>\mathbf{0 . 5})\end{array}$ \\
\hline Autonomy & 0.87 & 0.77 & 0.69 \\
Proactiveness & 0.87 & 0.77 & 0.68 \\
Risk Taking & 0.91 & 0.85 & 0.77 \\
Innovativeness & 0.88 & 0.80 & 0.71 \\
Competitive Aggression & 1 & 1 & 1 \\
Radicalness & 0.90 & 0.85 & 0.69 \\
\hline
\end{tabular}

Table 3: Structural Model Results

\begin{tabular}{|c|c|c|c|}
\hline & & \\
\hline Paths
\end{tabular}

${ }^{\text {a }}$ Standardized coefficients

${ }^{\mathrm{c}}$ Criteria: $>0.31$

${ }^{\mathrm{e}}$ Criteria: $>0.5$ 
Table 4: Sequence Test Results

\begin{tabular}{|c|c|c|c|c|c|c|c|}
\hline \multicolumn{5}{|c|}{ Sequence Exhibited } & \multirow{2}{*}{$\begin{array}{c}\text { Percentage } \\
\text { of Cases }\end{array}$} & \multirow{2}{*}{\multicolumn{2}{|c|}{$\begin{array}{l}\text { Sequence progression } \\
\text { according to model }\end{array}$}} \\
\hline A & $\mathrm{P}$ & $\mathrm{R}$ & I & $\mathrm{C}$ & & & \\
\hline $\mathrm{H}$ & $\mathrm{H}$ & $\mathrm{H}$ & $\mathrm{H}$ & $\mathrm{H}$ & $19 \%$ & Yes & \multirow{6}{*}{$47 \%$} \\
\hline $\mathrm{H}$ & $\mathrm{H}$ & $\mathrm{H}$ & $\mathrm{H}$ & $\mathrm{L}$ & $5 \%$ & Yes & \\
\hline $\mathrm{H}$ & $\mathrm{H}$ & $\mathrm{H}$ & $\mathrm{L}$ & $\mathrm{L}$ & $0 \%$ & Yes & \\
\hline $\mathrm{H}$ & $\mathrm{H}$ & $\mathrm{L}$ & $\mathrm{L}$ & $\mathrm{L}$ & $1 \%$ & Yes & \\
\hline $\mathrm{H}$ & $\mathrm{L}$ & $\mathrm{L}$ & $\mathrm{L}$ & $\mathrm{L}$ & $3 \%$ & Yes & \\
\hline $\mathrm{L}$ & $\mathrm{L}$ & $\mathrm{L}$ & $\mathrm{L}$ & $\mathrm{L}$ & $21 \%$ & Yes & \\
\hline $\mathrm{H}$ & $\mathrm{H}$ & $\mathrm{H}$ & $\mathrm{L}$ & $\mathrm{H}$ & $2 \%$ & No & \multirow{26}{*}{$53 \%$} \\
\hline $\mathrm{H}$ & $\mathrm{H}$ & $\mathrm{L}$ & $\mathrm{H}$ & $\mathrm{H}$ & $4 \%$ & No & \\
\hline $\mathrm{H}$ & $\mathrm{H}$ & $\mathrm{L}$ & $\mathrm{H}$ & $\mathrm{L}$ & $2 \%$ & No & \\
\hline $\mathrm{H}$ & $\mathrm{H}$ & $\mathrm{L}$ & $\mathrm{L}$ & $\mathrm{H}$ & $0 \%$ & No & \\
\hline $\mathrm{H}$ & $\mathrm{L}$ & $\mathrm{H}$ & $\mathrm{H}$ & $\mathrm{H}$ & $10 \%$ & No & \\
\hline $\mathrm{H}$ & $\mathrm{L}$ & $\mathrm{H}$ & $\mathrm{H}$ & $\mathrm{L}$ & $1 \%$ & No & \\
\hline $\mathrm{H}$ & $\mathrm{L}$ & $\mathrm{H}$ & $\mathrm{L}$ & $\mathrm{H}$ & $3 \%$ & No & \\
\hline $\mathrm{H}$ & $\mathrm{L}$ & $\mathrm{H}$ & $\mathrm{L}$ & $\mathrm{L}$ & $2 \%$ & No & \\
\hline $\mathrm{H}$ & $\mathrm{L}$ & $\mathrm{L}$ & $\mathrm{H}$ & $\mathrm{H}$ & $2 \%$ & No & \\
\hline $\mathrm{H}$ & $\mathrm{L}$ & $\mathrm{L}$ & $\mathrm{H}$ & $\mathrm{L}$ & $1 \%$ & No & \\
\hline $\mathrm{H}$ & $\mathrm{L}$ & $\mathrm{L}$ & $\mathrm{L}$ & $\mathrm{H}$ & $3 \%$ & No & \\
\hline $\mathrm{L}$ & $\mathrm{H}$ & $\mathrm{H}$ & $\mathrm{H}$ & $\mathrm{H}$ & $4 \%$ & No & \\
\hline $\mathrm{L}$ & $\mathrm{H}$ & $\mathrm{H}$ & $\mathrm{H}$ & $\mathrm{L}$ & $1 \%$ & No & \\
\hline $\mathrm{L}$ & $\mathrm{H}$ & $\mathrm{H}$ & $\mathrm{L}$ & $\mathrm{H}$ & $1 \%$ & No & \\
\hline $\mathrm{L}$ & $\mathrm{H}$ & $\mathrm{H}$ & $\mathrm{L}$ & $\mathrm{L}$ & $3 \%$ & No & \\
\hline $\mathrm{L}$ & $\mathrm{H}$ & $\mathrm{L}$ & $\mathrm{H}$ & $\mathrm{H}$ & $0 \%$ & No & \\
\hline $\mathrm{L}$ & $\mathrm{H}$ & $\mathrm{L}$ & $\mathrm{H}$ & $\mathrm{L}$ & $1 \%$ & No & \\
\hline $\mathrm{L}$ & $\mathrm{H}$ & $\mathrm{L}$ & $\mathrm{L}$ & $\mathrm{H}$ & $1 \%$ & No & \\
\hline $\mathrm{L}$ & $\mathrm{H}$ & $\mathrm{L}$ & $\mathrm{L}$ & $\mathrm{L}$ & $9 \%$ & No & \\
\hline $\mathrm{L}$ & $\mathrm{L}$ & $\mathrm{H}$ & $\mathrm{H}$ & $\mathrm{H}$ & $2 \%$ & No & \\
\hline $\mathrm{L}$ & $\mathrm{L}$ & $\mathrm{H}$ & $\mathrm{H}$ & $\mathrm{L}$ & $0 \%$ & No & \\
\hline $\mathrm{L}$ & $\mathrm{L}$ & $\mathrm{H}$ & $\mathrm{L}$ & $\mathrm{H}$ & $1 \%$ & No & \\
\hline $\mathrm{L}$ & $\mathrm{L}$ & $\mathrm{H}$ & $\mathrm{L}$ & $\mathrm{L}$ & $2 \%$ & No & \\
\hline $\mathrm{L}$ & $\mathrm{L}$ & $\mathrm{L}$ & $\mathrm{H}$ & $\mathrm{H}$ & $1 \%$ & No & \\
\hline $\mathrm{L}$ & $\mathrm{L}$ & $\mathrm{L}$ & $\mathrm{H}$ & $\mathrm{L}$ & $2 \%$ & No & \\
\hline $\mathrm{L}$ & $\mathrm{L}$ & $\mathrm{L}$ & $\mathrm{L}$ & $\mathrm{H}$ & $1 \%$ & No & \\
\hline
\end{tabular}

